\title{
MARINE RESERVOIR CORRECTION FOR THE COCOS (KEELING) ISLANDS, INDIAN OCEAN
}

\author{
Quan Hua ${ }^{1,2} \bullet$ Colin D Woodroffe ${ }^{3} \bullet$ Mike Barbetti $^{4} \bullet$ Scott G Smithers ${ }^{5} \bullet$ Ugo Zoppi $^{1} \bullet$ \\ David Fink ${ }^{1}$
}

\begin{abstract}
Known-age corals from the Cocos (Keeling) Islands, Indian Ocean, have been analyzed by accelerator mass spectrometry (AMS) for radiocarbon to determine marine reservoir age corrections. The $\Delta \mathrm{R}$ value for the Cocos (Keeling) Islands is $66 \pm 12 \mathrm{yr}$ based on the analyses undertaken for this study. When our AMS and previously published dates for Cocos are averaged, they yield a $\Delta \mathrm{R}$ of $64 \pm 15 \mathrm{yr}$. This is a significant revision of an earlier estimate of the $\Delta \mathrm{R}$ value for the Cocos (Keeling) Islands of $186 \pm 66 \mathrm{yr}$ (Toggweiler et al. 1991). The (revised) lower $\Delta \mathrm{R}$ for the Cocos (Keeling) Islands is consistent with GEOSECS ${ }^{14} \mathrm{C}$ data for the Indian Ocean, and previously published bomb ${ }^{14} \mathrm{C}$ data for the Red Sea, Gulf of Aden, and Cocos Islands. The revised $\Delta \mathrm{R}$ is also close to values for the eastern Indian Ocean and adjacent seas. These suggest surface waters that reach the Cocos Islands might be partly derived from the far western Pacific, via the Indonesian throughflow, and might not be influenced by the southeast flow from the Arabian Sea.
\end{abstract}

\section{INTRODUCTION}

Exchanging with the atmosphere and the radiocarbon-depleted deep ocean, the surface ocean has a ${ }^{14} \mathrm{C}$ level intermediate between these 2 reservoirs. This causes an age offset between marine samples, which source their carbon at the surface ocean, and contemporaneous terrestrial samples. This age offset is known as the marine reservoir age (R) and can be several hundred years. To calibrate a ${ }^{14} \mathrm{C}$ age for a marine sample, one needs to know its marine reservoir age (Stuiver and Reimer 1986). Alternatively, the regional variation from the global marine model age for that sample, defined as $\Delta \mathrm{R}$, is required (Stuiver and Braziunas 1993; Stuiver et al. 1998). The $\Delta \mathrm{R}$ value, which is also known as the regional marine correction, accounts for regional deviations in ${ }^{14} \mathrm{C}$ due to variations in ocean circulation and air-sea exchange of $\mathrm{CO}_{2}$. The latter method is generally preferred for age calibration (Reimer and Reimer 2001) and $\Delta \mathrm{R}$ values are typically determined by dating pre-bomb known-age marine carbonates (Southon et al. 2002).

The Cocos (Keeling) Islands $\left(12^{\circ} \mathrm{S}, 9^{\circ} \mathrm{E}\right)$ are an isolated Australian atoll in the eastern Indian Ocean. An annual band chronology has recently been established for corals from this atoll, which covers most of the 20th century (Smithers and Woodroffe 2000, 2001). The corals were Porites microatolls and were collected alive in 1991 and 1992 from 2 reef-flat sites on the southern and eastern sides of Cocos that are freely connected to the open ocean. These Cocos corals offer the possibility of examining regional variability of ${ }^{14} \mathrm{C}$ in the surface waters of the eastern Indian Ocean during the past century. Here, we report $\Delta \mathrm{R}$ measurements on 5 known-age coral bands and a known-age museum specimen of Porites coral. Our new data, in conjunction with previously published ${ }^{14} \mathrm{C}$ data for the atoll (Toggweiler et al. 1991; Woodroffe et al. 1994), can be used to determine a reliable mean $\Delta \mathrm{R}$ marine correction for Cocos. This is important not only for reliably dating marine fossils of the Cocos Islands by ${ }^{14} \mathrm{C}$, but also to improve our knowledge of ocean circulation around the Cocos Islands and the eastern Indian Ocean.

\footnotetext{
${ }^{1}$ Australian Nuclear Science and Technology Organisation (ANSTO), PMB 1, Menai, New South Wales 2234, Australia.

${ }^{2}$ Corresponding author. Email: qhx@ansto.gov.au.

${ }^{3}$ School of Geosciences, University of Wollongong, Wollongong, New South Wales 2522, Australia.

${ }^{4}$ NWG Macintosh Centre for Quaternary Dating, Madsen Building F09, University of Sydney, New South Wales 2006, Australia.

${ }^{5}$ School of Tropical Environment Studies and Geography, James Cook University, Townsville, Queensland 4811, Australia.
}

(C) 2004 by the Arizona Board of Regents on behalf of the University of Arizona Proceedings of the 18th International Radiocarbon Conference, edited by N Beavan Athfield and R J Sparks RADIOCARBON, $\mathrm{Vol}$ 46, $\mathrm{Nr} 2,2004, \mathrm{p}$ 603-610 


\section{MATERIALS AND METHODS}

For this study, we used microatoll PP30, collected on the eastern side of the atoll from a reef-flat site that is freely connected to the open ocean (see Figure 1), for ${ }^{14} \mathrm{C}$ analysis. The coral was sampled alive in 1992 and no recrystallization has occurred. Five single annual bands, which grew in 1906, 1926, 1933, 1941, and 1950, were split for ${ }^{14} \mathrm{C}$ analysis using a dental drill. In addition, a museum specimen of Porites coral from Cocos, which was collected alive by Charles Darwin in 1836, was measured in this study to investigate possible changes in $\Delta \mathrm{R}$ over the past $150 \mathrm{yr}$. This specimen (sample number 42.12.14.24) is deposited in the Department of Zoology, The Natural History Museum, London.

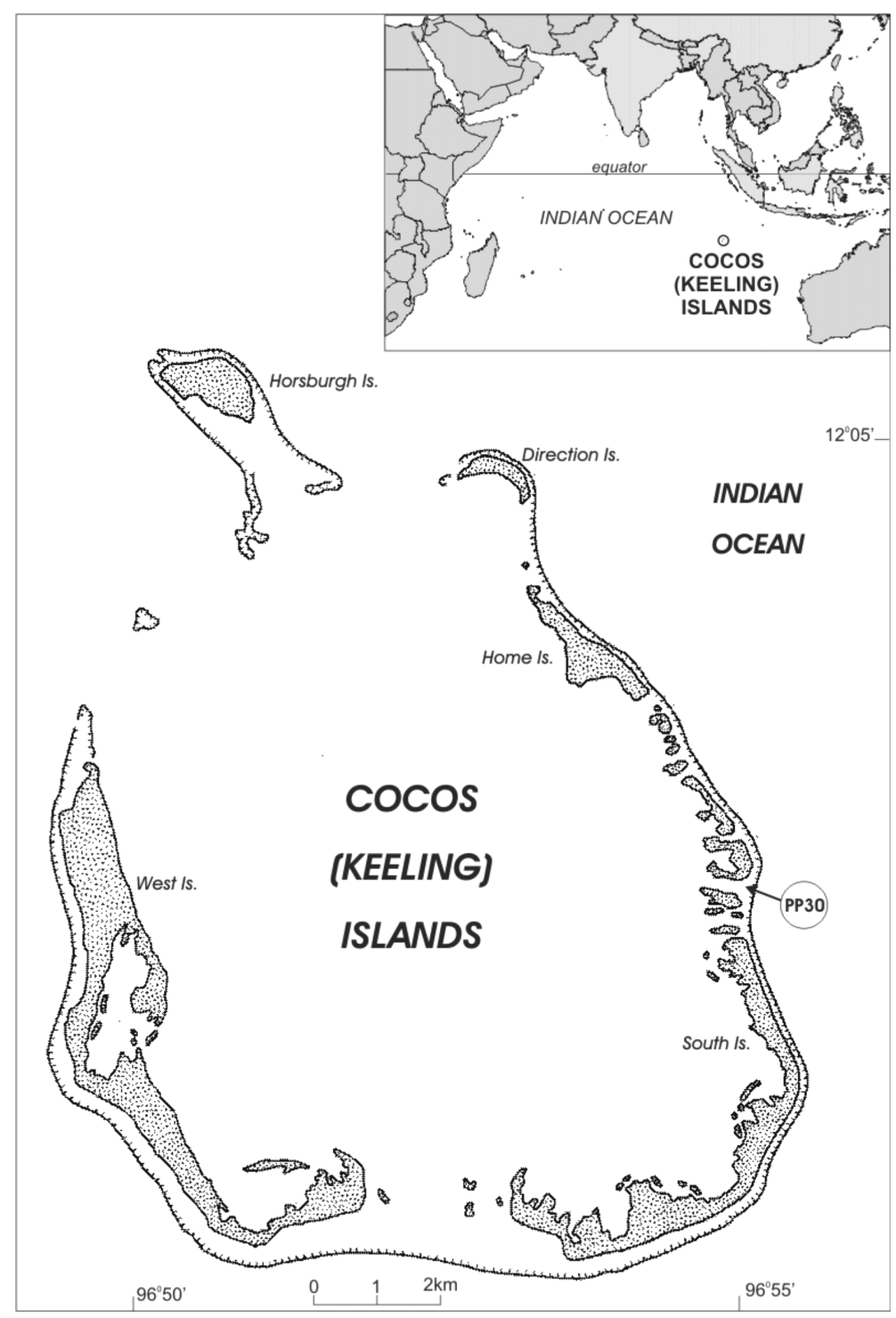

Figure 1 The Cocos (Keeling) Islands, showing location of open reef-flat microatoll PP30 
The samples were cleaned with deionized water in an ultrasonic bath 3 times for 20 min each to remove any surface contamination. They were then dried in an oven at $60{ }^{\circ} \mathrm{C}$ for 2 days before hydrolysis. The cleaned samples were hydrolyzed to $\mathrm{CO}_{2}$ using $85 \%$ phosphoric acid. The $\mathrm{CO}_{2}$ samples were then converted to graphite using the $\mathrm{Zn} / \mathrm{Fe}$ method. The technical aspects of these methods have been described in Hua et al. (2001). The mass of graphite was typically $4 \mathrm{mg}$. A small portion of graphite from each sample was employed for the determination of $\delta^{13} \mathrm{C}$ using the Micromass IsoPrime Elemental Analyser/Isotope Ratio Mass Spectrometer (EA/IRMS) at ANSTO. AMS ${ }^{14} \mathrm{C}$ measurements were performed using the ANTARES facility at ANSTO (Lawson et al. 2000; Fink et al. 2004) with a precision of $0.3-0.4 \%$.

\section{RESULTS}

The results of AMS ${ }^{14} \mathrm{C}$ measurements of the coral samples for this study are shown in Table 1 . The regional marine correction $\Delta \mathrm{R}$ (Stuiver and Braziunas 1993) is determined as the difference between the conventional ${ }^{14} \mathrm{C}$ age for each sample after correction for $\delta^{13} \mathrm{C}$ (Stuiver and Polach 1977) and the global marine model age for the year of collection or growth. To be compatible with the online marine reservoir correction database (Reimer and Reimer 2001), we used the 1998 marine calibration data set, Marine98 from Stuiver et al. (1998), as the model age of global ocean for the calculation of $\Delta \mathrm{R}$.

Table $1 \Delta \mathrm{R}$ values for the Cocos (Keeling) Islands, derived from corals. Note: [W-J] - Museum specimen collected by F Wood-Jones; [G-H] - Museum specimen collected by C A Gibson-Hill; [D] - Museum specimen collected alive by C Darwin. This specimen (sample number 42.12.14.24) is kept in the Department of Zoology, The Natural History Museum, London; and [S-W]- Annual coral band from open reef-flat microatoll PP30 (Smithers and Woodroffe 2000, 2001).

\begin{tabular}{|c|c|c|c|c|c|c|}
\hline Laboratory code & Coral species & $\begin{array}{l}\text { Year of growth } \\
\text { or collection }\end{array}$ & $\begin{array}{l}\delta^{13} \mathrm{C} \\
(\%)\end{array}$ & $\begin{array}{l}\text { Conventional } \\
{ }^{14} \mathrm{C} \text { age (yr BP) }\end{array}$ & $\begin{array}{l}\text { Model age } \\
(y r \text { BP) }\end{array}$ & $\begin{array}{l}\Delta \mathrm{R} \\
\left({ }^{14} \mathrm{C} \text { yr }\right)\end{array}$ \\
\hline \multicolumn{7}{|l|}{ Previous studies } \\
\hline L-DGO-1657 & - & 1941 & - & $652 \pm 66^{\mathrm{b}}$ & $466 \pm 8$ & $186 \pm 66$ \\
\hline ANU-6151 & $\begin{array}{l}\text { Acropora scherzeriana } \\
{[\mathrm{W}-\mathrm{J}]}\end{array}$ & 1906 & - & $370 \pm 60^{c}$ & $452 \pm 5$ & $-82 \pm 60$ \\
\hline ANU-6152 & Montipora foliosa [W-J] & 1906 & - & $670 \pm 60^{c}$ & $452 \pm 5$ & $218 \pm 60$ \\
\hline ANU-6153 & $\begin{array}{l}\text { Porites nigrescens } \\
(=P \text {. cylindrica })[\mathrm{W}-\mathrm{J}]\end{array}$ & 1906 & - & $410 \pm 60^{c}$ & $452 \pm 5$ & $-42 \pm 60$ \\
\hline ANU-7638 & $\begin{array}{l}\text { Montipora ramosa } \\
{[\mathrm{G}-\mathrm{H}]}\end{array}$ & 1941 & - & $510 \pm 70^{\mathrm{c}}$ & $466 \pm 8$ & $44 \pm 70$ \\
\hline ANU-7639 & $\begin{array}{l}\text { Montipora lobulata } \\
\text { [G-H] }\end{array}$ & 1941 & - & $480 \pm 60^{c}$ & $466 \pm 8$ & $14 \pm 61$ \\
\hline \multicolumn{7}{|l|}{ This study } \\
\hline OZG553 & Porites arenaceae [D] & 1836 & -2.8 & $586 \pm 29$ & $494 \pm 5$ & $92 \pm 29$ \\
\hline OZG956 & Porites $[\mathrm{S}-\mathrm{W}]$ & $1906 \pm 2^{\mathrm{d}}$ & -2.8 & $485 \pm 21$ & $452 \pm 6^{\mathrm{e}}$ & $33 \pm 22$ \\
\hline OZF535 & Porites $[\mathrm{S}-\mathrm{W}]$ & 1926 & -2.0 & $530 \pm 25$ & $456 \pm 4$ & $74 \pm 25$ \\
\hline OZF536 & Porites [S-W] & 1933 & -3.5 & $565 \pm 25$ & $460 \pm 5$ & $105 \pm 25$ \\
\hline OZF537 & Porites [S-W] & 1941 & -3.0 & $510 \pm 25$ & $466 \pm 8$ & $44 \pm 26$ \\
\hline OZF538 & Porites [S-W] & 1950 & -4.1 & $540 \pm 25$ & $472 \pm 13$ & $68 \pm 28$ \\
\hline
\end{tabular}

${ }^{a}$ Estimated value from decadal Marine 98 data (Stuiver et al. 1998) by linear interpolation.

${ }^{\mathrm{b}}$ Calculated from $\Delta{ }^{14} \mathrm{C}$ data from Toggweiler et al. (1991).

${ }^{\mathrm{c}}$ Data reported in Woodroffe et al. (1994).

${ }^{\mathrm{d}}$ Estimated uncertainty in age of growth band reflects the occurrence of zones of ambiguous growth band definition within the coral skeleton (Smithers and Woodroffe 2001).

eEstimated model age for AD $1906 \pm 2$. 
In addition, ${ }^{14} \mathrm{C}$ data for the Cocos (Keeling) Islands from previous studies (Toggweiler et al. 1991; Woodroffe et al. 1994) are presented in Table 1 . A summary of the $\Delta \mathrm{R}$ marine correction values for Cocos from previous studies and this investigation are plotted in Figure 2.

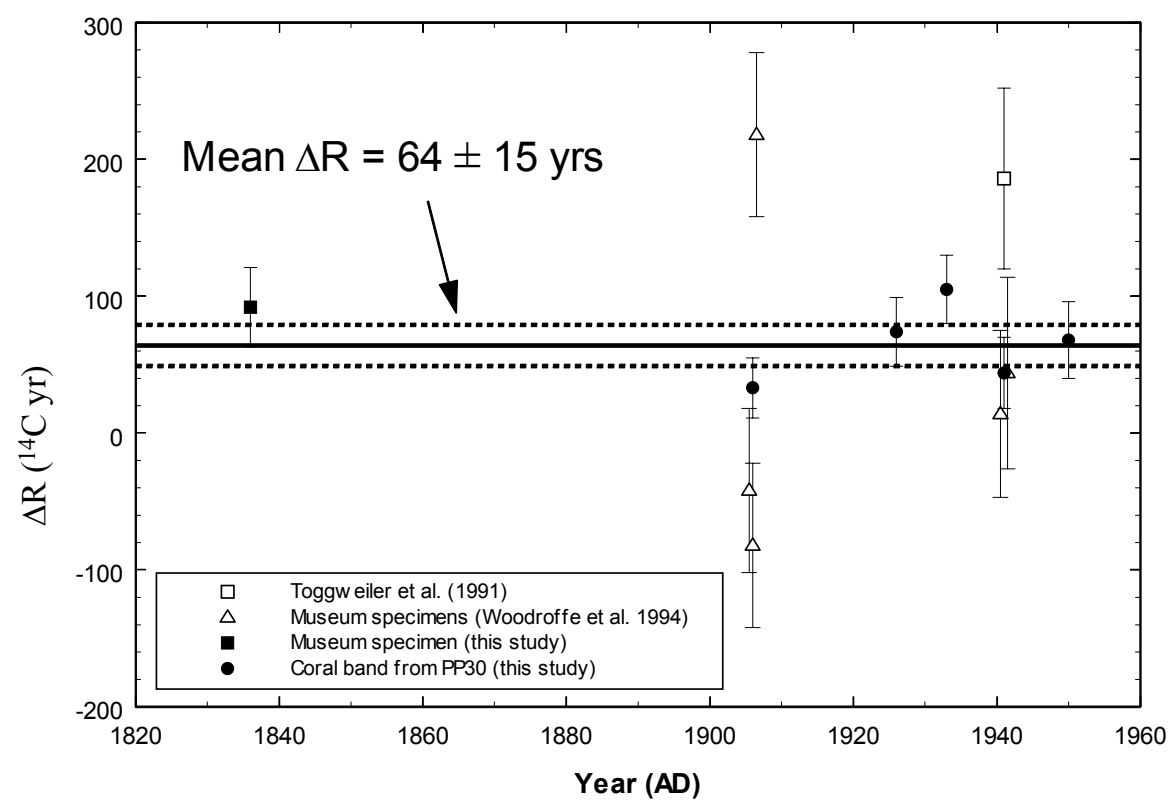

Figure $2 \Delta \mathrm{R}$ marine corrections for the Cocos (Keeling) Islands from previous studies and this investigation. The error-weighted mean value of $\Delta \mathrm{R}$ for Cocos is $64 \pm 15 \mathrm{yr}$.

\section{DISCUSSION}

The marine corrections for the Cocos (Keeling) Islands from this study show a small variation ranging from 33 to $105 \mathrm{yr}$ (Table 1 and Figure 2). This variation in our data may indicate the temporal variability in ${ }^{14} \mathrm{C}$ of surface ocean waters around the Cocos Islands for the past $150 \mathrm{yr}$. The average $\Delta \mathrm{R}$ marine correction value for the Cocos Islands is $66 \pm 12 \mathrm{yr}$ based on the analyses undertaken for this study. To be compatible with the online marine reservoir correction database (Reimer and Reimer 2001), the uncertainty associated with an error-weighted mean $\Delta \mathrm{R}$ was chosen as the larger of the error of the mean and the standard error. When compared with the previously published ${ }^{14} \mathrm{C}$ data for Cocos, our $\Delta \mathrm{R}$ value for 1941 ( $44 \pm 26 \mathrm{yr}$ ) is in good agreement with those (44 $\pm 70 \mathrm{yr}$ and $14 \pm 61 \mathrm{yr}$ ) of Woodroffe et al. (1994), but all these $3 \Delta \mathrm{R}$ values are significantly lower than that of Toggweiler et al. (1991) (186 $\pm 66 \mathrm{yr})$. For the 1906 data from Woodroffe et al. (1994), the first (Acropora scherzeriana) and third (Porites nigrescens) $\Delta \mathrm{R}$ values overlap within $1 \sigma$ uncertainty, but they are significantly lower than the second $\Delta \mathrm{R}$ (Montipora foliosa; see Table 1, Figure 2). Our $\Delta \mathrm{R}$ value for $1906(33 \pm 22 \mathrm{yr})$ overlaps with their third $\Delta \mathrm{R}$ value $(-42 \pm 60 \mathrm{yr})$ within $1 \sigma$ uncertainty, but is significantly different from their first $(-82 \pm 60 \mathrm{yr}$ ) and second $(218 \pm 60 \mathrm{yr}) \Delta \mathrm{R}$ values.

The large spreads in $\Delta \mathrm{R}$ values (300 $\mathrm{yr}$ for 1906 and $170 \mathrm{yr}$ for 1941) of the previously published data may be due to the spatial variability within the Cocos lagoon. However, the location of the museum specimens collected by Wood-Jones [W-J] and Gibson-Hill [G-H] (see Table 1), which were presumably collected alive, is largely unknown. Several of the specimens are likely to have been collected from the lagoon, such as Montipora foliosa, Porites nigrescens, and Montipora lob- 
ulata (Wells 1950). In addition, no details of sample species and location for Toggweiler et al.'s sample of 1941 were reported. On the other hand, the lagoon of the Cocos (Keeling) Islands, which is enclosed by 26 islands and covers a surface area of $190 \mathrm{~km}^{2}$, is well connected with the open ocean through tidal currents, indicated by a short flushing time of the lagoon between 5.4 and 2.3 days for neap and spring tidal conditions, respectively (Kench 1994). One may argue that the large spreads in the previously published data are simply due to experimental scatter. However, a scatter of this magnitude ( 170 to $300 \mathrm{yr}$ ) is too large to be accounted for in normal ${ }^{14} \mathrm{C}$ analyses, leaving the excessive $\Delta R$ spreads for 1906 and 1941 samples unexplained. When our AMS and previously published dates for Cocos are averaged, they yield a $\Delta \mathrm{R}$ marine correction of $64 \pm 15 \mathrm{yr}$. This is a significant revision of an earlier estimate of the $\Delta \mathrm{R}$ value for Cocos of $186 \pm 66 \mathrm{yr}$ (Toggweiler et al. 1991), which has recently been restated in the literature (Southon et al. 2002).

The ${ }^{14} \mathrm{C}$ data for the Indian Ocean from the Geochemical Ocean Section Study (GEOSECS) program during 1977-1978 showed that bomb ${ }^{14} \mathrm{C}$ appears less abundantly in the west Indian Ocean than in the east Indian Ocean (Stuiver and Östlund 1983). In other words, ${ }^{14} \mathrm{C}$ levels in surface waters of the western Indian Ocean are generally lower than those of the eastern Indian Ocean, resulting in $\Delta \mathrm{R}$ values that are higher in the western Indian Ocean than those for the eastern Indian Ocean. This is due to the intense monsoon-driven upwelling which takes place off the Somali and southern Arabian coasts and to a lesser extent off Pakistan and India (Southon et al. 2002 and references therein). Our revised $\Delta \mathrm{R}$ value of $64 \pm 15 \mathrm{yr}$ for the Cocos (Keeling) Island is consistent with the above GEOSECS ${ }^{14} \mathrm{C}$ data as it is lower than the $\triangle \mathrm{R}$ values of the tropical southwest Indian Ocean (135 $\pm 24 \mathrm{yr})$, western Arabian Sea $(207 \pm 30 \mathrm{yr})$, and eastern Arabian Sea (187 $\pm 25 \mathrm{yr})$ (see Table 2 and Figure 3).

Table $2 \Delta \mathrm{R}$ values for the Indian Ocean and adjacent seas from previous studies. All $\Delta \mathrm{R}$ values were calculated using the 1998 marine calibration data set (Marine98; Stuiver et al. 1998) as the model age of global ocean. The first $9 \Delta \mathrm{Rs}$ are regional marine corrections. The last $4 \Delta \mathrm{Rs}$ are marine corrections for a site or a small region. The first 8 regional $\Delta$ Rs were reported in Reimer and Reimer (2001).

\begin{tabular}{|c|c|c|c|c|}
\hline Region or Location & Latitude & Longitude & References & $\begin{array}{l}\Delta \mathrm{R} \\
\left({ }^{14} \mathrm{C} y r\right)\end{array}$ \\
\hline Western Arabian Sea $(\mathrm{N}=8)$ & $11-24^{\circ} \mathrm{N}$ & $43-58^{\circ} \mathrm{E}$ & - & $207 \pm 30$ \\
\hline Eastern Arabian Sea $(\mathrm{N}=16)$ & $7-25^{\circ} \mathrm{N}$ & $66-80^{\circ} \mathrm{E}$ & - & $187 \pm 25$ \\
\hline Bay of Bengal $(\mathrm{N}=6)$ & $9-13^{\circ} \mathrm{N}$ & $78-94^{\circ} \mathrm{E}$ & - & $64 \pm 55$ \\
\hline Northwest Australia - Java (N=9) & $7-18^{\circ} \mathrm{S}$ & $106-132^{\circ} \mathrm{E}$ & - & $64 \pm 24$ \\
\hline Northeast Australia $(\mathrm{N}=5)$ & $10-12^{\circ} \mathrm{S}$ & $141-143^{\circ} \mathrm{E}$ & - & $50 \pm 31$ \\
\hline Tropical southwest Indian Ocean $(\mathrm{N}=12)$ & $6-21^{\circ} \mathrm{S}$ & $39-56^{\circ} \mathrm{E}$ & - & $135 \pm 24$ \\
\hline South Africa $(\mathrm{N}=2)$ & $30-34^{\circ} \mathrm{S}$ & $18-31^{\circ} \mathrm{E}$ & - & $218 \pm 38$ \\
\hline South China Sea $(N=10)$ & $1-17^{\circ} \mathrm{N}$ & $99-121^{\circ} \mathrm{E}$ & - & $-17 \pm 17$ \\
\hline Southwest Australia (N=4) & $32-35^{\circ} \mathrm{S}$ & $115-117^{\circ} \mathrm{E}$ & $\begin{array}{l}\text { Gillespie (1977) } \\
\text { Gillespie and Polach (1979) } \\
\text { Bowman and Harvey (1983) } \\
\text { Bowman (1985) }\end{array}$ & $66 \pm 46$ \\
\hline Raffles Bay, N. Australia (N=1) & $11^{\circ} \mathrm{S}$ & $132^{\circ} \mathrm{E}$ & Southon et al. (2002) & $58 \pm 40$ \\
\hline Pelebuhanratu, S. Java (N=1) & $7^{\circ} \mathrm{S}$ & $107^{\circ} \mathrm{E}$ & Southon et al. (2002) & $40 \pm 70$ \\
\hline Port Sudan, Red Sea (N=3) & $20^{\circ} \mathrm{N}$ & $37-38^{\circ} \mathrm{E}$ & $\begin{array}{l}\text { Cember (1989) } \\
\text { Southon et al. (2002) }\end{array}$ & $120 \pm 28$ \\
\hline Djibouti, Gulf of Aden (N=5) & $11-13^{\circ} \mathrm{N}$ & $43-45^{\circ} \mathrm{E}$ & $\begin{array}{l}\text { Toggweiler et al. (1991) } \\
\text { Southon et al. (2002) }\end{array}$ & $193 \pm 36$ \\
\hline
\end{tabular}




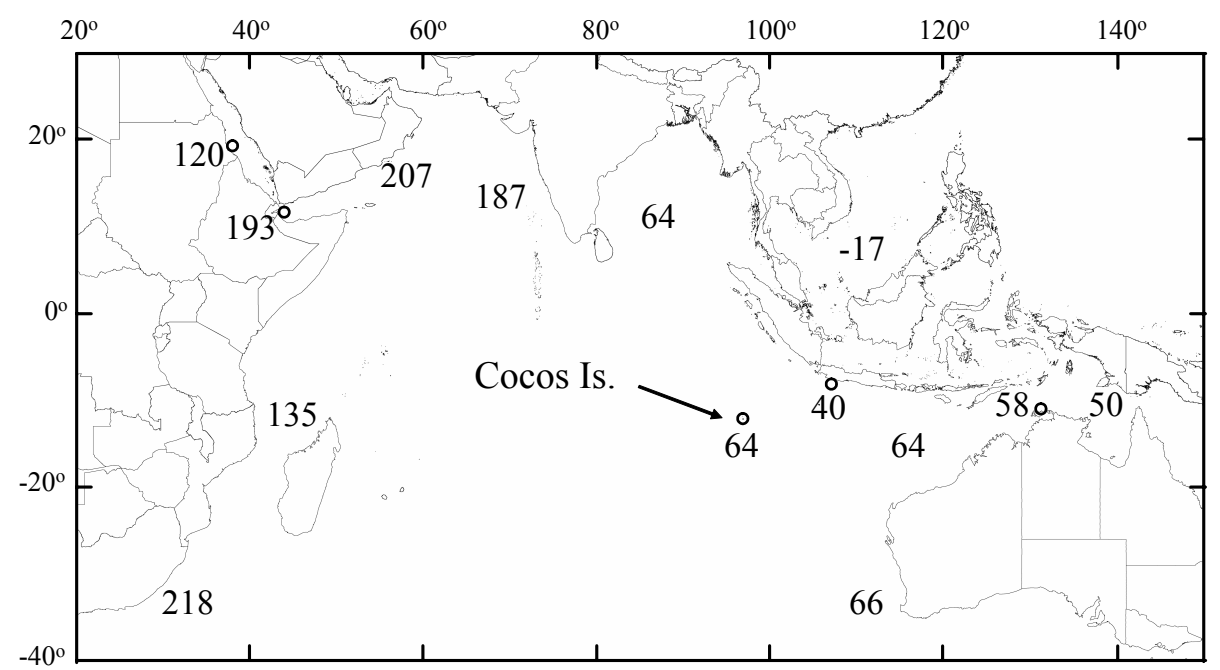

Figure $3 \Delta \mathrm{R}$ marine corrections for the Indian Ocean and adjacent seas with our revised $\Delta \mathrm{R}$ value for the Cocos (Keeling) Islands. $\Delta \mathrm{R}$ for a region is shown by its value in the middle of the region. $\Delta \mathrm{R}$ for a site or a small region is shown by its value with an open circle indicating the location of the site or small region. The details of these $\Delta \mathrm{R}$ marine corrections are given in Table 2.

Published bomb ${ }^{14} \mathrm{C}$ data derived from corals from the northwestern Indian Ocean-Port Sudan $\left(20^{\circ} \mathrm{N}, 37^{\circ} \mathrm{E}\right.$, the Red Sea; Cember 1989$)$ and Djibouti $\left(11^{\circ} \mathrm{N}, 43^{\circ} \mathrm{E}\right.$, Gulf of Aden; Toggweiler et al. 1991) - compared to those from the Cocos (Keeling) Islands (Toggweiler et al. 1991) are shown in Figure 4. We have also measured ${ }^{14} \mathrm{C}$ in annual bands of corals from the Cocos (Keeling) Islands for 1955-1985 (the bomb pulse period). There is a good agreement between our preliminary results and the data from Toggweiler et al. (1991) for 1970-1976. However, reporting and discussing our bomb ${ }^{14} \mathrm{C}$ results for Cocos are beyond the scope of this paper. Bomb ${ }^{14} \mathrm{C}$ for the Cocos Islands is higher than that for Port Sudan, which, in turn, is higher than bomb ${ }^{14} \mathrm{C}$ for Djibouti. These bomb ${ }^{14} \mathrm{C}$ data also support the revised $\Delta \mathrm{R}$ value for the Cocos Islands as it (64 $\pm 15 \mathrm{yr})$ is lower than the $\Delta \mathrm{R}$ of Port Sudan of $120 \pm 28 \mathrm{yr}$, which, in turn, is lower than that of Djibouti of $193 \pm 36 \mathrm{yr}$ (see Table 2 and Figure 3). Like other parts of the northwest Indian Ocean, the Gulf of Aden is a region of monsoondriven seasonal upwelling (Cember 1989). This explains why there are high $\Delta \mathrm{R}$ and low $\Delta^{14} \mathrm{C}$ values for Djibouti (Gulf of Aden) and, consequently, medium-high $\Delta \mathrm{R}$ and medium-low $\Delta^{14} \mathrm{C}$ values for Port Sudan as surface waters of the Red Sea are partly derived from those of the Gulf of Aden through the Straits of Bab-el-Mandeb (Cember 1989).

When compared with the marine corrections for the east Indian Ocean (Table 2 and Figure 3), the revised $\Delta \mathrm{R}$ of $64 \pm 15 \mathrm{yr}$ for the Cocos (Keeling) Islands is close to values for the eastern Indian Ocean, e.g., $40 \pm 70 \mathrm{yr}$ for Pelebuhanratu (South Java; Southon et al. 2002) and $64 \pm 24 \mathrm{yr}$ for northwest Australia and Java (Reimer and Reimer 2001). The Cocos $\Delta \mathrm{R}$ value is also similar to those for Raffles Bay, northern Australia (58 $\pm 40 \mathrm{yr}$; Southon et al. 2002) and Torres Strait and northeastern Australia (50 \pm 31 yr; Reimer and Reimer 2001), but significantly higher than that for the South China Sea ( $-17 \pm 17 \mathrm{yr}$; Reimer and Reimer 2001). In addition, the Cocos $\Delta \mathrm{R}$ value is significantly lower than those for the western Indian Ocean as discussed above. These suggest surface waters that reach the Cocos Islands might be partly derived from the far western Pacific, flowing through the Indonesian seas (Fieux et al. 1994; Moore et al. 1997), and might not be influenced by the southeast flow from the Arabian Sea as suggested by Southon et al. (2002). 


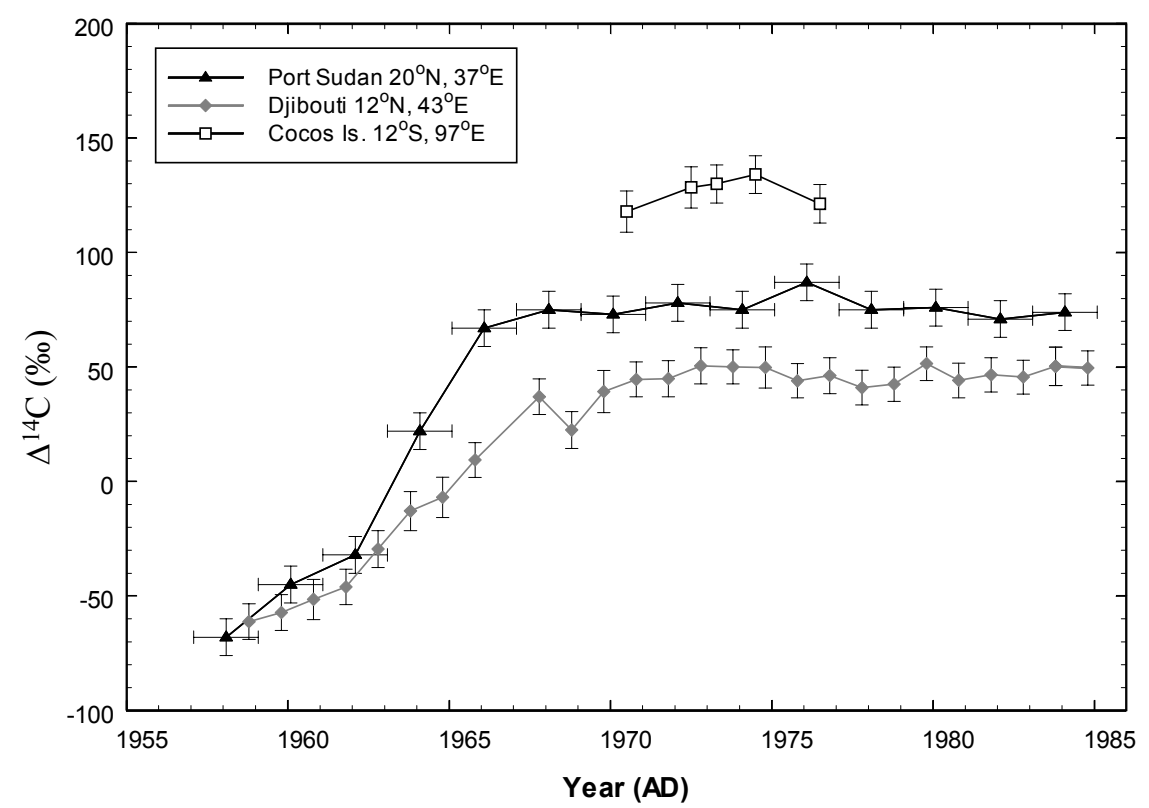

Figure 4 Published bomb ${ }^{14} \mathrm{C}$ data from corals from Port Sudan (the Red Sea; Cember 1989), Djibouti (Gulf of Aden; Toggweiler et al. 1991), and the Cocos (Keeling) Islands (Toggweiler et al. 1991). Djibouti and Cocos records consisted of annual data, meanwhile Port Sudan data were biannual data.

\section{ACKNOWLEDGEMENTS}

The authors wish to thank Brian Rosen (Department of Zoology, The Natural History Museum, London) for the supply of a museum specimen of Porites coral collected by Charles Darwin (sample number 42.12.14.24). We would like to thank Holly Yeatman for helping with sample preparation and Alan Williams for $\delta^{13} \mathrm{C}$ measurements, both at ANSTO. The authors also thank John Southon (Earth System Science Department, University of California, Irvine) for his useful comments which helped improve the manuscript. We gratefully acknowledge funding from the Australian Institute of Nuclear Science and Engineering (AINSE) for AMS ${ }^{14} \mathrm{C}$ measurements (grants 01/207 and 02/ $150 \mathrm{P})$.

\section{REFERENCES}

Bowman GM. 1985. Revised radiocarbon oceanic reservoir correction for southern Australia. Search 16:164 5.

Bowman GM, Harvey N. 1983. Radiocarbon dating marine shells in South Australia. Australian Archaeology 17:113-23.

Cember RP. 1989. Bomb radiocarbon in the Red Sea: a medium scale gas exchange experiment. Journal of Geophysical Research 94:2111-23.

Fieux M, Andrie C, Delecluse P, Ilahude AG, Kartavtseff A, Mantisi F, Molcard R, Swallow JC. 1994. Measurements within the Pacific-Indian oceans flowthrough region. Deep Sea Research 41:1091-130.

Fink D, Hotchkis MAC, Hua Q, Jacobsen GE, Smith AM, Zoppi U, Child D, Mifsud C, van der Gaast HA,
Williams AA, Williams M. Forthcoming. The ANTARES AMS Facility at ANSTO. Nuclear Instruments and Methods in Physics Research B.

Gillespie R. 1977. Sydney University natural radiocarbon measurements IV. Radiocarbon 19:101-10.

Gillespie R, Polach HA. 1979. The suitability of marine shells for radiocarbon dating of Australian prehistory. In: Berger R, Suess HE, editors. Radiocarbon Dating. Proceedings of the 9th International ${ }^{14} \mathrm{C}$ Conference. Berkeley: University of California Press. p 404-21.

Hua Q, Jacobsen GE, Zoppi U, Lawson EM, Williams AA, Smith AM, McGann MJ. 2001. Progress in radiocarbon target preparation at the ANTARES AMS Centre. Radiocarbon 43(2A):275-82.

Kench P. 1994. Hydrodynamic observations of the Cocos 
(Keeling) Islands Lagoon. Atoll Research Bulletin 408:1-21.

Lawson EM, Elliott G, Fallon J, Fink D, Hotchkis MAC, Hua Q, Jacobsen GE, Lee P, Smith AM, Tuniz C, Zoppi U. 2000. AMS at ANTARES-the first 10 years. Nuclear Instruments and Methods in Physics Research B 172:95-9.

Moore MD, Schrag DP, Kashgarian M. 1997. Coral radiocarbon constraints on the source of the Indonesian throughflow. Journal of Geophysical Research 102(C6):12,359-65.

Reimer PJ, Reimer RW. 2001. A marine reservoir correction database and on-line interface. Radiocarbon 43(2A):461-3. URL: http://www.calib.org/.

Smithers SG, Woodroffe CD. 2000. Microatolls as sealevel indicators on a mid-ocean atoll. Marine Geology 168:61-78.

Smithers SG, Woodroffe CD. 2001. Coral microatolls and 20th century sea level in the eastern Indian Ocean. Earth and Planetary Science Letters 191:173-84.

Southon J, Kashgarian M, Fontugne M, Metivier B, Yim W. 2002. Marine reservoir corrections for the Indian Ocean and Southeast Asia. Radiocarbon 44(1):16780.
Stuiver M, Braziunas TF. 1993. Modelling atmospheric ${ }^{14} \mathrm{C}$ influences and ${ }^{14} \mathrm{C}$ ages of marine samples to 10,000 BC. Radiocarbon 35(2):137-89.

Stuiver M, Östlund HG. 1983. GEOSECS Indian Ocean and Mediterranean radiocarbon. Radiocarbon 25(1): $1-29$.

Stuiver M, Polach HA. 1977. Discussion: reporting of ${ }^{14} \mathrm{C}$ data. Radiocarbon 19(3):353-63.

Stuiver M, Reimer PJ. 1986. A computer program for radiocarbon age calibration. Radiocarbon 28(2B): 1022-30.

Stuiver M, Reimer PJ, Braziunas TF. 1998. High-precision radiocarbon age calibration for terrestrial and marine samples. Radiocarbon 40(3):1127-51.

Toggweiler JR, Dixon K, Broecker WS. 1991. The Peru upwelling and the ventilation of the South Pacific thermocline. Journal of Geophysical Research 96(C11):20,467-97.

Wells JW. 1950. Reef corals from the Cocos-Keeling Atoll. Bulletin of Raffles Museum 22:29-52.

Woodroffe CD, McLean RF, Wallensky E. 1994. Geomorphology of the Cocos (Keeling) Islands. Atoll Research Bulletin 402:1-33. 